\title{
VÖRÖSMARTY AND THE ROMANTIC FRAGMENT
}

\author{
MIHÁLY SZEGEDY-MASZÁK \\ Indiana University, Bloomington, IND, \\ USA
}

Although Sándor Petőfi (1823-1849) may be internationally more famous than Mihály Vörösmarty (1800-1855), it is possible to argue that the older author can be regarded as the most representative poet of Hungarian Romanticism, who in his best lyrics has a force that not even Petőfi could attain. Petöfi's descriptive and humorous poems could be characterized as representing a Biedermeier reaction against the sublimity of the most important works of the older poet, but it would be a distortion to deny that some of Petófi's finest lyrics - the cycle of epigrams called Felhök (Clouds, 1845-46) or the longer poem Tündérálom (Fairy Dream, 1846) - show the decisive influence of Vörösmarty's Romanticism. In any case, Vörösmarty is an author who cannot be neglected in any international history of Romantic poetry.

His works were often called fragmentary. "A földi menny (Earthly Paradise, 1825), Helvila halálán (On the Death of Helvila, 1822-23), and Helvila (To Helvila, 1822-23) resemble chaos (Zerrbild)," János Erdélyi (1814-1868) wrote in 1845 (Erdélyi 1991, 27). What this important critic missed in his contemporary's poetry was a metonymic structure. In his view Vörösmarty "merely juxtaposes the constituents of the story, instead of linking them together"2 (Erdélyi 1991, 37). Taking the example of the short epic Cserhalom (1825), he insisted that causality was hardly perceptible in the works of Vörösmarty, so that the knightly virtues of the early medieval King Ladislas I "were not given proper poetic justification; they seemed accidental"3 (Erdélyi 1991, 69). What he meant was not simply that Vörösmarty was an imperfect story-teller for he detected a similar weakness in the lyrics: the poem entitled Fóti dal (A Song Composed in Fót, 1842) "does not constitute a whole; it is a disorderly heap of beauties. (...) Its course is meandering, instead of moving in a definite direction; it is full of arbitrary and accidental elements"4 (Erdélyi 1991, 36). Such observations lead to the following conclusion: "He has undeniable great poetic strength, but he creates mere chaos rather than a finely shaped world"5 (Erdélyi 1991, 37).

What Erdélyi described as Vörösmarty's main shortcoming is comparable both to Friedrich Schlegel's concept of irony as the consciousness of infinite and total 
chaos $^{6}$ (Schlegel 1967, 263) and to the charges brought against some English Romantics by Quarterly Review (Hayden 1969). If "architectonic rules," "preliminary planning and a sense of proportion," as well as "formal maturity, structural wholeness" " are the criteria (Erdélyi 1991, 80), it becomes understandable that such works as $A$ Délsziget (An Island in the South, 1826) and Magyarvár (A Hungarian Fortress, 1827) are not even mentioned. Erdélyi's ideal of form is a far cry from Friedrich Schlegel's view that a fragment can be regarded as a finished work of $\operatorname{art}^{8}$ (Schlegel 1967, 197). Although it is often maintained that Erdélyi in contrast to the literary historian Ferenc Toldi (1805-1875), a great admirer of Vörösmarty - was a spokesman of Petőfi's popular style and viewed Vörösmarty's works from the perspective of his own interest in folklore, in this respect the difference between the two interpreters was negligible. The earlier of the two above-mentioned poems was characterized by Toldi as an example of "symbolic" expression in which "adventureous imagination slips into the bizarre, so that allusions become entirely incomprehensible" (Toldy 1987, 247). As for A Hungarian Fortress, this work attracted Toldy's attention on account of its subject: the poetic reconstruction of the beliefs of the pagan ancestors of the Hungarians. In his view the poet had left it as a fragment, because "he lacked historical and legendary material for it"10 (Toldy 1987, 247).

For Erdélyi a poem was successful only if "it constituted a whole (...), in the same way as different tones created harmony in music." It was a serious flaw if some element "surprised the reader on account of its being unexpected, in the sense that it could not be traced back to any perceptible cause"11 (Erdélyi 1991, 81). The analysis of $A$ Rom (The ruin, 1830) makes it clear that Erdélyi associated artistic perfection with "poetic judgement." His idea that the function of literature was to illustrate moral lessons and render instruction to the readers was in conflict with Vörösmarty's natural inclinations. "Since it is difficult to identify the meaning of this allegory," the critic wrote, "the poet should have published this poem as a fragment" 12 (Erdélyi 1991, 234). Toldy's observation that in this poem "Ruin is mistakenly raised to the status of a god that controls human fate"13 (Toldy 1987, 247 ) is even more symptomatic of contemporary critics' inability to recognize that Vörösmarty was a master of the disruption of the reader's expectations who brought a new complexity and new uneasiness to the art of poetry.

In the first half of the nineteenth century Hungarians used the word "fragment" very much in the same way as most other Europeans: they referred either to objects that had lost some of their parts or to unfinished products. Born in Transdanubia, a region full of Roman (Pannonian) and medieval (Romanesque and Gothic) ruins, Vörösmarty was keenly aware of the first of these meanings. At the same time, he was the first major Hungarian poet to publish works that were meant to remain fragments. As such, An Island in the South and A Hungarian Fortress marked a radical departure from a widely respected convention. They 
raised the fragment to the status of an aesthetic form that represented the relation between the individual and ideal unity.

English poems describing ruins had been known in Hungary before 1800. Such lyrics as Régi várban (In an Old Fortress, 1825) or Huszt (1831) by Ferenc Kölcsey (1790-1838) treated ruins as metonymies of national history, and the broken horn of a pagan Hungarian warrior was evoked to remind the reader of the destructive force of time in Lehel kürtje (Lehel's Horn) by János Garay (1812-1853). Similar connotations can be discovered in Rom (A Ruin) by Lőrinc Tóth (1814-1903), a poem published in the almanach Emlény (Memoirs) in 1838. All these lyrics may have been inspired by the campaign started by Miklós Jankovich (1773-1846). His article Esedezés a magyar régiségek iránt (In Defence of Hungarian Antiquities), published in the scholarly journal Tudományos Gyüjtemény (Scholarly Collection) in 1818, urged contemporary Hungarians to discover "important historical ruins" in order to learn how much had been "destroyed irrevocably" during the Ottoman occupation of the sixteenth and seventeenth centuries (Marosi 1999, 15).

While other poets looked upon ruins as reminders of the vicissitudes of Hungarian history, Vörösmarty interpreted them as symbols of the mode of existence of artistic creations. In this sense even his longest epic, Zalán futása (The Flight of Zalán, 1825) could be called fragmentary. Erdélyi characterized it as such, on the basis of its lack of a hero and a focus. János Horváth, the most influential Hungarian literary historian of the first half of the twentieth century, argued in a similar way when he published a selection from this work, insisting that each "lyrical passage" had to be read "as a separate poem" (Vörösmarty 1925, 4). Many of the sentences slip by like fleeting visions, giving the poem a sense of caprice and fragility, so that the writing gives the impression of an unconstrained improvisation that refuses to bend to any formula. Characteristically, Vörösmarty insisted on the similarities between his dislocated and truncated syntax and the rhapsodic, improvisatory, rubato playing of his great contemporary in Liszt Ferenchez (To Ferenc Liszt, 1840) and described the gypsy fiddler as his "Doppelgänger" in $A$ vén cigány (The Old Gypsy, 1854). The poet's malaise experienced with large, unified forms testifies to a loss of faith and interest in the calculated balances and clear articulations that an epic implied. It corresponds to a mistrust of the Enlightenment interpretation of progress that is most explicitly formulated in the long meditative poem Gondolatok a könyvtárban (Thoughts in a Library, 1844), a radical questioning of the utility of books.

Erdélyi's essay and Horváth's selection played a major role in the history of the reception of Vörösmarty's poetry. Both insisted that the uncertainty of progress, the missing link, discontinuity, and the unexpected make the impression that this poet's works are fragmentary in nature. It is true that Vörösmarty had such models as Virgil's Aeneid and the Ossianic poems, but he succeeded in making it seem as if his poetry had been created sui generis. His work is marked by a continual 
disparity between traditional form and innovation, public expectation and a penchant for introspection. Instead of focusing on Árpád, the warrior who led the ancestors of the Hungarians into the Carpathian basin, he made the defeated Zalán the main character of his epic. Untimely death, life cut short by some unexpected event is the recurrent motif of The Flight of Zalán as well as of the elegy Kis gyermek halálára (On the Death of a Young Child, 1824), A két szomszédvár (The Two Neighbouring Fortresses, 1832), a verse tale in four cantos, the romance Szép Ilonka (Fair Ilonka, 1833), and the epitaph Hubenayné (Mrs. Hubenay, 1844). Using the splintering into fragments as a formal principle, he liberated Hungarian verse from the academic requirements of the past. There is great originality in his ability to move from one vision to the next without preparation. From The Flight of Zalán to Elöszó (A Foreword, 1850) and The Old Gypsy his poems are full of visionary images highlighting the unpredictability of natural forces.

The title A Foreword refers to a missing centre. The introduction starts as if in the middle of an already initiated narrative:

When I wrote this, the sky was clear, ${ }^{14}$

The three stanzas are of unequal length, and this irregular division is at odds with the equally uneven segmentation based on tenses. The structure is determined by a disturbed solar system: a full summer is suddenly interrupted by a winter of nothingness, and the future is presented as a spring not associated with youth, but with old age (cf. Szegedy-Maszák 1988, esp. 236). The syntax is so fragmentary that sometimes it suggests the inarticulate:

Now it is winter and silence and snow and death. ${ }^{15}$

The narrative of an unfulfilled promise refers to a second creation that remains incomplete. Vörösmarty was not a poet whose object was pleasure. The cosmic catastrophe is found contrary to all experience, yet is presented as true. A spiritual life is imparted to nature: the visionary offers an account of how nature assists in making the human mind aware of its mirror in what it sees. The poem is a preface to an unwritten work. The history of the 1848 revolution has been transformed into cosmic events.

The sudden interruption of continuity is often linked to the image of the sublime in Vörösmarty's poetry. Similarly to Wordsworth (Wordsworth 1988, 267), the Hungarian poet interpreted the sublime as a state of consciousness. What deeper principle may underlie the unexpected, sudden ("rasch") changes between past and present, present and future? Such are the questions asked in A Foreword. For the title hero of The Ruin and the warring families in The Two Neighbouring Fortresses the world is not given but is in a state of constant deconstruction. The fiftysix-line monologue on night at the beginning of the fifth act of Vörösmarty's 
verse play Csongor és Tünde (Csongor and Tünde, 1831), a "Menschheitsdichtung" with characters taken "from the age of pagan Cumanians," presents nothingness as existing before the creation and after the dissolution of the universe:

There will be dark nothingness, I alone will exist, A dreary, silent, uninhabited night. ${ }^{16}$

Csongor and Tünde is one of the most important among Vörösmarty's major works suggesting that the world lacks unity and lies broken in fragments because man is disunited with himself. In certain respects, this five-act lyrical drama, inspired by fairy tales, História egy Árgirus nevü királyfiról és egy tündér szüzleányról (The Story of Prince Argirus and a Fairy Virgin) - a verse narrative composed by Albert Gergei in the late sixteenth century - and A Midsummer Night's Dream, may be regarded as the poet's refuge from adult tumult, the manifestation of the Romantic belief that a man of creative genius has retained the spirit of infancy into the era of adulthood. Vörösmarty's poetry, however, is almost never free of dark connotations. There is often, even in the most serene sections, an undercurrent of turbulence. The text of Csongor and Tünde is dominated by metaphors of fragmentary existence. In Act I Ilma, a peasant woman in the service of the heroine, compares her fate to a broken ship that cannot reach its goal, and Tünde's hair - suggesting magic power - is cut by an old witch. In Act II Csongor is tortured by a vision of incompleteness:

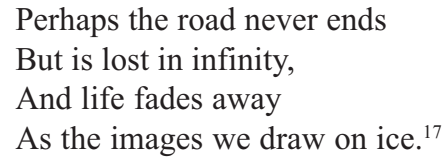

Each of the three wanderers the hero meets - the Merchant, the Prince, and the Scholar - talks of plenitude, but in the final act the ideal of each turns out to be fragmentary: what they lack seems to be more essential to human existence than what they possess. Market-oriented utilitarianism, political power, and knowledge are presented as equally defective. The comic counterparts of these wanderers, three goblins inherit three objects which cannot be used separately, so each has a legacy that is of no value (cf. Szegedy-Maszák 1994, esp. 302-304).

In contrast to the interpretation of human existence characteristic of the works of such Romantics as Wordsworth, Coleridge, or Emerson, Vörösmarty's apocalyptic vision implies a denial of the belief that "nothing can befall on the poetic self which nature cannot repair." His image of a disjointed, tortured, cruel, and alienated nature is closer to Baudelaire's interpretation: nature is seen not as the nurturing, mothering, healing, educating solace of life but as a system of spiritual signs warning of the primacy of destruction, a force that conspires with the supernatural to ruin mankind. At least two of the later lyrics, Az emberek (Men, 1846) 
and $A$ Foreword, give a vision of history as a self-destructive process governed by eternal recurrence. In the earlier poem disruptions catch the reader by surprise, beginning with the first words:

Keep silence, stop singing,

Let the world speak. ${ }^{18}$

Reason and evil, law and oppression are depicted as natural allies, Cain is regarded as the originator of an everlasting tradition, and in the final stanza of the same poem the human species is called "the teeth of a dragon." In A Foreword spring is portrayed as an old whore who has killed her children, and in The Old Gypsy a question is asked about the identity of some creature crying "as a mill in hell." In the first two of these major poems the violation is of such a nature that no ultimate resolution can be imagined, because the terms of resolution have been basically denied.

During the first half of the nineteenth century Vörösmarty was not the only Hungarian poet to believe that the workings of consciousness were comparable to sudden illuminations rather than a continuous stream. In the third (and final) stanza of Egy töredék alá (On a Fragment, 1840), by Boldizsár Adorján (1820-1867), the idealist emphasis on completeness was discarded as irrelevant in view of the fragmentation of the soul. Images of the double were often linked to loss of sanity, in the same way as "fragments of most touching melody" were used as a metonymy of madness in Shelley's Julian and Maddalo (1824). Following the lead of Jean-Jacques Rousseau, Hungarian authors gave a psychological justification for syntactic fragmentation. The predominance of coordinate sentences is conspiculous not only in Men, A Foreword, and The Old Gypsy but also in the verse of lesser poets. Vörösmarty was the most important but not the only poet to publish fragments. In 1836 even Sándor Kisfaludy (1772-1844), of the previous generation, presented his work A somlai vérszüret: Rege a magyar elöidökböl (Mass Destruction in Somló: A Legend from the Hungarian Prehistoric Era) as a fragment to the members of the Hungarian Academy of Sciences, and the following year he published it as a (deliberately) unfinished text. What sets the works of Vörösmarty apart from those of his Hungarian contemporaries is that it is possible to see a deeper justification for fragmentation. The unity described at the beginning of An Island in the South is replaced by a division. The island is split and each of the two main characters (Szüdeli and Hadadúr) is surrounded by a fragmentary world, separated by an abyss that is both frightening and sublime. The absence of verbal predicates characterizes not only this poem but also A Hungarian Fortress. The legendary hero of this second fragmentary epic is a fugitive prince who is compared to both Prometheus and Lear. At the end of his life Vörösmarty translated King Lear into Hungarian. This highly imaginative translation, together with the Hungarian Romantic's "original" works can prove that 
metaphoric writing may be closely related to a denial of continuity, rationalism, and progress. Although the Russian intervention of 1849 and the sad end of the Hungarian revolution deeply shocked Vörösmarty, and his life gradually ebbed away in a twilight state, illness and the progressive desolation in his spirit did not rob him of creative vigour: A Foreword and The Old Gypsy were written shortly before his death.

The fragmentary vision of existence that was criticized in the nineteenth century by those who spoke of Vörösmarty's awkwardness in handling the great forms made him one of the most original Hungarian poets in the eyes of later generations. The reader may find a powerful verbal innovation in his best works, the genius of a decision to break new ground in the expressive potential of metaphoric writing. What his contemporaries saw as a refusal to accept the responsibilities of large-scale form has proved to be an instransigence admired by twentieth-century poets. The old hierarchy of genres still ruled in the nineteenth century, although Vörösmarty's work, along with that of Petőfi, had shaken it. The final destruction came with the beginning of the twentieth century. That is one of the reasons why the poetry of Vörösmarty has more affinity with the style of the avant-garde than it does with the verse of the later nineteenth century. Mihály Babits (1883-1941), one of the leading poets of the Modernist movement, who called Petöfi "a petty bourgeois wearing the mask of a genius" (Babits 1910, 1586), discussed Vörösmarty's poetry as the most significant Hungarian contribution to Romantic literature (Babits 1911). The Romantic poet's apocalyptic visions of cosmic catastrophes exerted a profound influence on the verse of János Pilinszky (1921-1971), the most original Hungarian poet of the decades of Communist dictatorship. It could be said without exaggeration that Vörösmarty's work served as a constant source of inspiration for later poets. Like other major Romantics, he set an example for those who desired to make inherited diction untenable and create a new poetic discourse.

\section{Notes}

1. “A földi menny, Helvila halálán, és Helvila mindegyik ráma és körrajz nélküli szanakép (Zerrbild) vagy töredék."

2. "nem füzi össze lánccá, hanem csak egymás mellé teszi a történet szemeit."

3. "László udvariassága nincs kellőleg, azaz, költőileg vive, mert csak mint eset, véletlen történet adatik elénk."

4. "a Fóti dal nem egy, nem egész, hanem szépségek rendetlen halmaza, összetákolása (...) a dalmenet irányt vesztve, kalandozni kezd (...) mintegy erővel behúzva, és véletlenül.”

5. “Öbenne nagy költői erő lakik, tagadhatlan, de véve a költő értelmét ugy is, mint aki nemcsak puszta chaoszt teremteni, hanem belőle szép formáju világot is tud alkotni, akkor máskép fog esni válaszunk."

6. "Ironie ist klares Bewusstsein der ewigen Agilität, des unendlich vollen Chaos." 
7. “architektonikus szabály”, “átgondoltság s bizonyos lelki szemmérték”, "az arányosság, kimért tisztaság, formai meglettség, alaki teljesség."

8. "Ein Fragment muss gleich einem kleinen Kunstwerke von der umgebunden Welt ganz abgesodert und in sich selbst vollendet sein wie ein Igel."

9. “egy nagyobb jelves (szimbolikus) költemény eleje, melyben a kalandos képzelem a bizarrig tévedez, s célzásaiban teljesen érthetetlenné lesz."

10. "mondai és történeti anyag hia miatt végre is abbanhagyta azt."

11. "úgy alkotna összehangzó egészet (...), mint zenemúvész különböző hangokból harmóniát (...) meglep váratlansága miatt, mert nem látjuk elegendő okát előbbeniekben.”

12. "Mi legyen ezen allegoria értelme (...). Kivenni bajos (...), azért jobb lett volna ezt is töredékül adni ki."

13. "Romisten helytelenül tétetik az emberi sors intézőjévé."

14. "Midőn ezt irtam, tiszta volt az ég,"

15. "Most tél van és csend és hó és halál."

16. "Sötét és semmi lesznek: én leszek, Kietlen, csendes, lény nem lakta Éj."

17. "Vagy tán vége sincs az útnak, Végtelenbe téved el, $S$ rajta az élet úgy vész el, Mint mi képet jégre irunk?"

18. "Hallgassatok, ne szóljon a dal, Most a világ beszél."

\section{Bibliography}

Babits, Mihály (1910). "Petőfi és Arany," Nyugat 3, 1577-1590.

Babits, Mihály (1911). "Az ifjú Vörösmarty," "A férfi Vörösmarty,” Nyugat 4, vol. 2, 689-701, 1041-1061.

Erdélyi, János (1991). Irodalmi tanulmányok és pályaképek. Budapest: Akadémiai Kiadó.

Hayden, John O. (1969). The Romantic Reviewers 1802-1824. Chicago: The University of Chicago Press.

Marosi, Ernő (ed.) (1999). A magyar müvészettörténetírás programjai: Válogatás két évszázad irásaiból. Budapest: Corvina.

Schlegel, Friedrich (1967). Charakteristiken und Kritiken I (1796-1801). Hg. v. Hans Eichner. München: Ferdinand Schöningh.

Szegedy-Maszák, Mihály (1988). "Romanticism in Hungary," in Roy Porter and Mikuláš Teich, eds. Romanticism in National Context. Cambridge: Cambridge University Press, 217-239.

Szegedy-Maszák, Mihály (1994). "Romantic Drama in Hungary," in Gerald Gillespie, ed. Romantic Drama. Amsterdam: John Benjamins, 297-315.

Toldy, Ferenc (1987). A magyar nemzeti irodalom története. A legrégibb idöktöl a jelenkorig. Rövid elöadásban 1864-1865. Budapest: Szépirodalmi Kiadó.

Vörösmarty, Mihály (1925). Anthologia. Budapest: Magyar Irodalmi Társaság.

Wordsworth, William (1988). Selected Prose. Harmondsworth, Middlesex: Penguin Books. 